\title{
PENGETAHUAN MANAJEMEN PETERNAKAN DAN PEMANFAATAN HASIL TERNAK SEBAGAI SUMBER GIZI MASYARAKAT DI KECAMATAN BARON KABUPATEN NGANJUK
}

\author{
KNOWLEDGE OF LIVING AND UTILIZATION MANAGEMENT RESULTS OF LIVESTOCK AS A \\ COMMUNITY NUTRITION SOURCE IN BARON DISTRICT, NGANJUK REGENCY
}

\author{
Sunaryo Hadi Warsito \\ Fakultas Kedokteran Hewan \\ Oky Setyo Widodo \\ Fakultas Kedokteran Hewan \\ Shelly Wulandari \\ Fakultas Vokasi
}

\begin{abstract}
ABSTRAK
Masyarakat di Kecamatan Kertosono rata-rata memiliki mata pencaharian bertani dan berdagang. Hampir semua dari warga masyarakat yang berprofesi sebagai petani memiliki hewan ternak yang dipelihara sebagai usaha atau mata pencaharian sampingan. Ternak yang dipelihara antara lain sapi potong, kambing, dan domba. Permasalahan-permasalahan yang timbul antara lain: Masyarakat belum sepenuhnya memahami bagaimana cara memperoleh daging hasil sembelihan hewan qurban dengan kualitas yang baik, Masyarakat belum mengetahui penyakit-penyakit yang bersifat zoonosis, serta Masyarakat masih belum banyak yang mengetahui bagaimana tata cara proses penyembelihan ternak yang baik. Tujuan utama dalam kegiatan pengabdian kepada masyarakat ini adalah dapat meningkatkan pengetahuan dan keterampilan warga masyarakat mengenai kriteria daging ASUH (Aman, Sehat, Utuh, dan Halal) serta handling dan restraint yang sesuai pada ternak.
\end{abstract}

Kata kunci: Kecamatan Kertosono, Kabupaten Nganjuk, ASUH, Handling, Restraint

\section{ABSTRACT}

The community in Kertosono Subdistrict has an average farming and trading livelihood. Almost all of the people who work as farmers have livestock that are kept as a side business or livelihood. Livestock that are kept include beef cattle, goats and sheep. The problems that arise include: The community has not fully understood how to obtain meat from the sacrifice of qurban animals with good quality. The public does not know of zoonotic diseases, and there are still not many people who know how the procedures for slaughtering livestock are good. The main objective in this community service activity is to be able to increase the knowledge and skills of the community regarding the criteria for ASUH meat (Safe, Healthy, Whole, and Halal) and appropriate handling and restraint on livestock.

Keywords: Kertosono Subdistrict, Nganjuk District, ASUH, Handling, Restraint

\section{PENDAHULUAN}

Kecamatan Baron berbatasan dengan Kecamatan Kertosono di sebelah timur, sebelah selatan hingga barat berbatasan dengan Kecamatan Tanjunganom, serta sebelah utara berbatasan dengan Kecamatan Lengkong. Pusat pemerintahan Kecamatan Baron terletak tepat di tepi jalan utama Surabaya-Jogja, jalur ini juga dilewati oleh bis antar provinsi sehingga letak kecamatan Baron cukup strategis. Kelurahan Garu dan Kelurahan Jekek adalah bagian dari Kecamatan Baron. Terletak kurang lebih 4 km dari pusat pemerintahan kecamatan, sekitar $25 \mathrm{~km}$ dari ibukota kabupaten, dan sekitar $110 \mathrm{~km}$ dari ibukota Provinsi Jawa Timur.

Kelurahan Garu memiliki luas wilayah 189,19 Ha, dimana tanah sawah dan irigasi teknis yang penggunaannya masih tergolong banyak yaitu sekitar 89,22 Ha. Secara geografis Kelurahan Garu merupakan dataran rendah wilayah pertanian daerah pengaliran laut atau daerah pengaliran sungai, dengan kemiringan 10-20 persen dan suhu rata-rata per harinya $30^{\circ} \mathrm{C}$. Menurut topografinya Kelurahan Garu 
termasuk dataran rendah yang berkarakter tanah liat dan termasuk tanah gerak, sehingga akses jalan menuju desa masih mengalami kesulitan. Namun dengan kondisi lahan yang subur menjadikan daerah ini sebagai penghasil lumbung pangan padi, tebu, dan bawang yang potensial di Kabupaten Nganjuk. Mayoritas mata pencaharian warga adalah petani, buruh tani, dan peternak.

Kelurahan Jekek memiliki luas wilayah sekitar 425 Ha, dengan batas sebelah utara Kecamatan Baron, batas selatan Kelurahan Kemlokolegi, batas timur Kelurahan Kemaduh, dan batas barat Kelurahan Katerban. Jarak dari pusat pemerintahan kecamatan sekitar $4 \mathrm{~km}$, jarak dari ibukota kabupaten sekitar $25 \mathrm{~km}$, dan jarak dari ibukota provinsi Jawa Timur sekitar $110 \mathrm{~km}$. mata pencaharian mayoritas warga Kelurahan Jekek tidak jauh berbeda dengan warga Kelurahan Garu, yaitu sebagai petani, buruh tani, dan peternak.

Para warga yang memiliki ternak sebagai sumber penghasilan lain selain sector usaha pertanian rata-rata masih menerapkan pola pemeliharaan yang konvensional. Ternak di tempatkan pada kandang yang sederhana dan diberikan pakan rumput atau hijauan seadanya tanpa memperhitungkan kebutuhan nutrisi dari masing-masing ternak. Bila dapat dipelihara secara lebih professional, hasil ternak tersebut dapat optimal dan bias menjadi mata pencaharian utama warga sekitar.

\section{PERMASALAHAN MITRA}

Berdasarkan hasil diskusi dengan kepala desa dan beberapa perwakilan masyarakat pada bulan Februari 2017, teridentifikasi beberapa permasalahan, permasalahan tersebut mengarah pada manajemen peternakan yang masih kurang baik dan kurang optimalnya produksi ternak yang dimiliki oleh warga. Manajemen peternakan dalam hal ini adalah seluruh aspek-aspek yang berpengaruh pada usaha peternakan, seperti: nutrisi pakan ternak, konstruksi kandang, sanitasi kandang, cara pemeliharaan, program vaksinasi atau pengobatan, pemilihan bibit, hingga faktor produksi dan reproduksi ternak.

Rata-rata warga masyarakat masih minim informasi tentang manajemen peternakan yang baik dan benar sehingga hasil produksi ternak yang dihasilkan belum optimal. Selain itu edukasi mengenai nilai nutrisi yang terkandung dalam bahan pangan asal hewan juga sangat diperlukan guna membuka wawasan masyarakat tentang konsumsi gizi yang seimbang.

\section{SOLUSI YANG DITAWARKAN}

Berdasarkan analisis terhadap suatu akar permasalahan seperti yang telah diuraikan diatas, maka solusi yang ditawarkan untuk dapat meningkatkan informasi masyarakat tentang manajemen pemeliharaan ternak dan kesadaran masyarakat akan kebutuhan gizi dari bahan pangan asal hewan adalah dengan cara memberikan penyuluhan tentang tata cara pemeliharaan ternak sapi, kambing dan domba, serta unggas yang baik dan benar meliputi nutrisi pakan ternak, konstruksi kandang, sanitasi kandang, cara pemeliharaan, program vaksinasi atau pengobatan, pemilihan bibit, hingga faktor produksi dan reproduksi ternak; pembagian buku modul yang berisi tentang tata cara pemeliharaan ternak yang informatif dan mudah dipahami oleh peternak; serta melakukan demo pembuatan makanan olahan dari bahan pangan asal hewan.

Peternakan adalah kegiatan mengembangbiakkan dan membudi dayakan hewan ternak untuk mendapatkan manfaat dan hasil dari kegiatan tersebut. Pengertian peternakan tidak terbatas pada pemeliharaan saja, memelihara dan peternakan perbedaannya terletak pada tujuan yang ditetapkan. Tujuan peternakan adalah mencari keuntungan dengan penerapan prinsip-prinsip manajemen pada factor-faktor produksi yang telah dikombinasikan secara optimal (Rasyaf, 1994).

Berdasarkan ukuran hewan ternak, bidang peternakan dapat dibagi menjadi dua golongan, yaitu peternakan hewan besar seperti sapi, kerbau, kuda, kambing, dan domba sedangkan kelompok hewan kecil seperti ayam, kelinci, dan lain-lain (Sayuti, 2006). Hewan ternak yang dimiliki oleh warga Kelurahan Garu dan Kelurahan Jekek Kecamatan Baron diantaranya adalah sapi, kambing, domba, dan ayam.

Produk hewan adalah segala macam bahan yang didapatkan dari tubuh hewan, seperti daging, lemak, darah, susu, telur, enzim, dan sebagainya (Unklesbay, 1992). Dalam kegiatan pengabdian masyarakat ini akan dilakukan praktek pengolahan dari bahan pangan asal hewan berupa daging sapi dan daging ayam.

\section{METODE PELAKSANAAN}

Metode pelaksanaan yang akan digunakan dalam program pengabdian masyarakat ini adalah penyuluhan dan diskusi. Tujuan dari penyuluhan yang dilakukan kepada warga masyarakat adalah memberikan gambaran umum tentang manajemen peternakan yang baik dan selanjutnya dilakukan diskusi yang mendalam tentang tata cara beternak sapi, kambing, domba, dan ayam. Setelah acara penyuluhan dan diskusi selesai, dilanjutkan dengan edukasi pembuatan makanan berbahan dasar daging ayam dan daging sapi yang diolah menjadi nugget. Dengan demikian pengetahuan para warga masyarakat dapat semakin bertambah dan mendorong untuk dapat lebih meningkatkan pemenuhan kebutuhan gizi masyarakat dan kesejahteraan ternak masyarakat. Penyuluhan penting dilakukan untuk dapat mengubah pola pikir para warga masyarakat yang rata-rata masih 
konvensional hingga dapat menerima transfer pengetahuan dari tim pengabdian masyarakat dari Fakultas Kedokteran Hewan Universitas Airlangga.

Setelah dilakukan penyuluhan dan praktek dilanjutkan dengan forum diskusi kembali. Pada forum diskusi dan tanya jawab ini warga masyarakat dapat berbagi pengalaman, mengemukakan pendapat, serta mengajukan pertanyaan pada tim pengabdian masyarakat mengenai manajemen peternakan dan pengolahan bahan pangan asal hewan. Dari forum diskusi dapat disimpulkan tentang masalah nyata yang terjadi di masyarakat dan ditemukan solusi untuk permasalahan tersebut.

Setelah program pengabdian masyarakat telah selesai dilaksanakan, dilakukan evaluasi pelaksanaan program. Evaluasi pelaksanaan program dilakukan dengan cara terus memantau tingkat kesadaran masyarakat akan kebutuhan gizinya dan manajemen pemeliharaan ternak yang dilakukan pada setiap periode KKN BBM yang diterjunkan pada desa tersebut.

\section{PELAKSANAAN PROGRAM}

Kegiatan pengabdian kepada masyarakat ini dilakukan pada tanggal 3 Agustus 2017. Bertepatan dengan periode penerjunan mahasiswa KKN BBM Universitas Airlangga. Kegiatan dilaksanakan pada malam hari, yaitu sekitar pukul 20.00 WIB. Hal ini dikarenakan ketika pagi dan siang hari tidak memungkinkan untuk mengumpulkan warga dengan berbagai kesibukan. Rata-rata warga masyarakat masih sibuk bekerja di waktu pagi hingga siang hari. Tempat kegiatan difasilitasi oleh Kepala Desa, lokasi kegiatan penyuluhan bertempat di balai desa.

Pembukaan acara diawali dengan sambutan dari Kepala Desa, dilanjutkan sambutan dari Dosen Pembina Pembangunan Desa (DP2D), dan sambutan dari ketua kelompok KKN BBM Universitas Airlangga. Kepala Desa menyampaikan rasa terima kasih kepada tim pengabdian kepada masyarakat Universitas Airlangga karena merasa mendapatkan perhatian dari pihak universitas dengan diadakannya kegiatan di desanya. Harapannya agar hubungan baik dapat terus berlanjut dalam berbagai kegiatan yang positif untuk pembangunan desa.

Memasuki acara yang pertama yaitu penyuluhan tentang manajemen peternakan yang disampaikan oleh drh. Sunaryo Hadi Warsito, MP. Penyampaian materi berlangsung sekitar 45 menit dan di lanjutkan dengan sesi diskusi. Dalam sesi diskusi terlihat banyak warga masyarakat yang antusias untuk bertanya guna memperoleh informasi. Pertanyaan tidak hanya muncul dari bapak-bapak saja tetapi ibu-ibu juga antusias ingin bertanya. Rata-rata kaum ibu warga desa berprofesi sebagai ibu rumah tangga. Tidak hanya itu, kaum ibu juga banyak yang memiliki ternak di rumah.
Ketika suami mereka bekerja di luar daerah, ibu-ibu lah yang bertugas mengurusi ternak-ternaknya. Hewan yang diternakkan bermacam-macam, antara lain bebek, ayam, entok, kambing, domba, dan sapi.

Sesi ke dua yaitu pemutaran video cara pengolahan bahan pangan asal hewan menjadi berbagai macam olahan pangan. Ini bertujuan agar tidak hanya wawasan tentang dunia peternakan saja yang di sampaikan ke pada warga masyarakat tetapi tata cara pengolahan bahan pangan asal hewan juga diedukasikan. Warga masyarakat memiliki motivasi untuk membuat bahan pangan asal hewan sendiri, yang paling diminati adalah pembuatan nugget dari daging ayam. Masyarakat baru memahami bahwa membuat nugget itu mudah untuk dilakukan.

\section{KESIMPULAN}

Kesimpulan dari kegiatan pengabdian kepada masyarakat yang telah dilaksanakan adalah sebagai berikut:

1. Masih banyak warga masyarakat yang belum memahami tentang cara pemeliharaan ternak yang baik.

2. Warga masyarakat rata-rata masih belum mengetahui cara mengolah bahan pangan asal hewan menjadi produk olahan yang bernilai gizi tinggi.

\section{SARAN}

Saran yang dapat disampaikan dari kegiatan pengabdian kepada masyarakat ini adalah :

1. Perlu dibentuknya kader penyuluh desa mengenai kesadaran gizi masyarakat akan protein hewani

2. Perlu di lakukan pendampingan lebih lanjut, dalam hal ini oleh mahasiswa KKN BBM yang diterjunkan di lokasi dan oleh Dosen Pembina Pembangunan Desa (DP2D) tentang kegiatan manajemen peternakan dan pemanfaatan hasil peternakan yang dilakukan oleh warga.

\section{DAFTAR PUSTAKA}

Rasyaf M. 1994. Manajemen Peternakan Ayam Kampung. Yogyakarta: Kanisius.

Sayuti A. 2006. Geografi Budaya Dalam Wilayah Pembangunan Daerah Sumatera Barat Departemen Pendidikan Dan Kebudayaan Proyek Inventarisasi Dan Dokumentasi Kebudayaan Daerah.

Unklesbay, Nan. 1992. World Food And You. Routledge. P. 1979 Ff. 